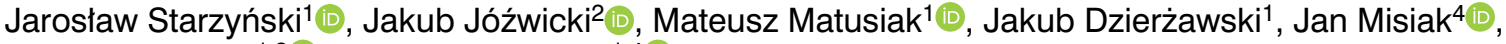
Anna A. Brożyna ${ }^{1,3(0)}$, Wojciech Jóźwicki ${ }^{1,4}$

1Department of Tumour Pathology and Pathomorphology, Oncology Centre-Prof. Franciszek Łukaszczyk Memorial Hospital, Bydgoszcz, Poland

${ }^{2}$ Department of Clinical Pathomorphology, Faculty of Medicine, Ludwik Rydygier Collegium Medicum in Bydgoszcz, Nicolaus Copernicus University in Torun, Bydgoszcz, Poland

${ }^{3}$ Department of Human Biology, Faculty of Biology and Environment Protection, Nicolaus Copernicus University, Toruń, Poland

${ }^{4}$ Department of Tumour Pathology and Pathomorphology, Ludwik Rydygier Collegium Medicum in Bydgoszcz, Nicolaus Copernicus University in Torun, Bydgoszcz, Poland

\title{
The effect of ROR $\alpha$ expression on the development of biological malignancy of urinary bladder cancer
}

\section{Corresponding author:}

Wojciech Jóźwicki, Department of Tumour Pathology

and Pathomorphology, Oncology

Centre-Prof. Franciszek Łukaszczyk Memorial Hospital, Bydgoszcz.

Poland, e-mail: jozwickiw@

co.bydgoszcz.pl
Medical Research Journal 2019; Volume 4, Number 3, 129-135 10.5603/MRJ.a2019.0024 Copyright (C) 2019 Via Medica ISSN 2451-2591

\begin{abstract}
Background: Morbidity and mortality relating to urinary bladder cancer have remained largely unchanged for many years. Similarly, the five-year survival rate in this disease has not improved considerably. New developments in individualized therapy necessitate the search for novel factors that could predict the development of malignancy in UBC. In this study, we provide the first evidence that the expression of ROR alpha transcription factor influences the development of malignancy in UBC.

Materials and methods: 105 patients with stage pT1-pT4 urothelial bladder carcinoma who underwent cystectomy were included in the study. $4 \mu \mathrm{m}$ tissue samples were stained immunohistochemically with a polyclonal anti-ROR $\alpha$ antibody. The expression of ROR $\alpha$ by the tumor cells (TCs) was assessed by counting TCs with a cytoplasmic and/or nuclear staining for ROR $\alpha$ per 1000 TCs. The association between the extent of ROR $\alpha$ expression and non-classic differentiation, tumor advancement (pT), grade (G) and regional lymph node spread was analyzed.

Results: The cytoplasmic expression of ROR $\alpha$ was detected in near all analyzed tumor samples (104/105) The extent of ROR $\alpha$ expression was significantly higher in tumors which were more malignant with more propensity for non-classic differentiation and lymph node metastasis. We noted a lower percentage of TCs expressing ROR $\alpha$ in poorly differentiated tumors (G3), compared to tumors moderately and higher differentiated (G1/G2).

Conclusions: Our results suggest that $\mathrm{ROR} \alpha$ may play a significant role in the progression of urinary bladder cancer. $\mathrm{ROR} \alpha$ has a broad spectrum of regulatory activity relating to cell and tissue differentiation the mechanism of which is not fully understood. This study represents another step in the process of understanding the mechanisms of $\mathrm{ROR} \alpha$ regulation and highlights its potential role as a therapeutic target in urothelial bladder cancer.

Key words: ROR $\alpha$; UBC; urothelial bladder cancer; NDN; non-classic differentiation number; ND; non-classic differentiation; lymph node status
\end{abstract}

Med Res J 2019; 4 (3): 129-135

\section{Introduction}

Urinary bladder cancer (UBC) is one of the most frequently diagnosed cancers in the world [1] with a fourfold higher incidence rate in men [1-4] as well as an increasing prevalence of established risk factors such as smoking, overweight, physical inactivity, and changing reproductive patterns associated with urbanization and economic development. Based on GLOBOCAN estimates, about 14.1 million new cancer cases and 8.2 million deaths occurred in 2012 worldwide. Over the years, the burden has shifted to less developed countries, which currently account for about $57 \%$ of cases and $65 \%$ of cancer deaths worldwide. Lung cancer is the leading cause of cancer death among males in both more and less developed countries, and has surpassed 
breast cancer as the leading cause of cancer death among females in more developed countries; breast cancer remains the leading cause of cancer death among females in less developed countries. Other leading causes of cancer death in more developed countries include colorectal cancer among males and females and prostate cancer among males. In less developed countries, liver and stomach cancer among males and cervical cancer among females are also leading causes of cancer death. Although incidence rates for all cancers combined are nearly twice as high in more developed than in less developed countries in both males and females, mortality rates are only $8 \%$ to $15 \%$ higher in more developed countries. This disparity reflects regional differences in the mix of cancers, which is affected by risk factors and detection practices, and/or the availability of treatment. Risk factors associated with the leading causes of cancer death include tobacco use (lung, colorectal, stomach, and liver cancer. UBC is typically diagnosed in women in more advanced stages and appears to be more aggressive [4, 5]. Morbidity and mortality relating to UBC have not changed significantly for many years. Likewise, five-year survival rates have not improved $[4,6]$. Urothelial bladder carcinoma constitutes approximately $90 \%$ cases of UBC. Early detection of UBC allows for endoscopic removal of the tumor with transurethral resection of bladder tumor (TURBT) [7] including basic surgical techniques such as the obturator nerve block. Important basic surgical skills required for complete TURBT in non-muscle invasive bladder cancer are: (i. However, cancer recurrence is frequent recurrence rates of $50 \%$ one year after surgical treatment [8]. Disease progression in 10-20\% of those cases qualifies the patient for radical cystectomy [9]. In order to reduce the number of radical cystectomies and to personalize treatment regimens, it is necessary to search for new prognostic and predictive markers of malignancy in UBC. ROR $\alpha$ (retinoid acid-related orphan receptor alpha; RORA; NR1F1) belongs to the nuclear receptor family of transcription factors called retinoid-related orphan receptors which includes also $\operatorname{ROR} \beta$ and $\operatorname{ROR} \gamma$. Changes in the expression levels of nuclear receptors are observed in different types of cancers including melanoma, breast cancer or liver cancer [10-13]. RORs have a modular structure including a DNA binding domain (DBD) and a ligand binding domain (LBD) which are distinctive for nuclear receptors. RORs regulate transcription through DBD binding to specific regulatory DNA sequences (ROR Response Elements) in target genes. However, ROR Response Elements are not specific only for RORs. Other nuclear receptors including transcription repressors may compete for the binding sites of the regulatory DNA sequences in an antagonistic manner [14-17]. The presence of LBDs allows for the modulation of ROR activity by various molecules acting as agonists or antagonists which respectively enhance or suppress the effect of RORs on the transcription of target genes [18, 19]. Accordingly, RORs became an important research area in the biology of cancer due to their potential to become new targets for therapeutic strategies. Some studies demonstrate that RORs play critical roles in the regulation of a variety of physiological processes [20]. The orphan nuclear receptor ROR alpha has been shown to be involved in the control of cell growth and differentiation [21]. There are reports of the role of RORs in breast cancer [22], melanoma [10, 23], hepatocellular carcinoma [24], and colorectal cancer [25]. However, we are not aware of studies involving the role of RORs expression in UBC. In this study, we provide the first evidence that the expression of ROR alpha transcription factor influences the development of pT1-pT4 UBC as defined by histological and clinical indicators of malignancy including tumor advancement $(p T)$, grade (G), a number of non-classic differentiation types (NDN) and lymph node spread ( $\mathrm{pN})$.

\section{Materials and methods}

\section{Study group}

105 patients with pT1-pT4 urothelial bladder cancer who underwent radical cystectomy/cystoprostatectomy in from Oncology Centre-Prof. Franciszek Łukaszczyk Memorial Hospital in Bydgoszcz between 2011 and 2014 was included in the study. The median age of patients was 65 years. The mean age was 65 years (64 years in women and 65 years in men). The detailed characteristics of the study group are presented in Table 1. The study was approved by the Bioethics Committee at the Nicolaus Copernicus University in Torun, Collegium Medicum in Bydgoszcz, Poland (No: KB 587/2018).

\section{The preparation and assessment of H\&E stained samples}

Tissue sections were fixed in $10 \%$ buffered formalin and embedded in paraffin blocks according to a standard protocol. Tumor advancement (pT stage), histological malignancy (G), frequency of non-classic differentiation (ND) and the number of non-classic differentiation types (NDN) was assessed as previously described [26-29]. Staging and histological type of tumors were assessed according to the WHO TNM classification [30].

\section{The preparation and assessment of immunostained samples}

Immunohistochemical staining was performed on $4 \mu \mathrm{m}$ tissue sections with the use of polyclonal anti-ROR $\alpha$. Antigen retrieval was performed in a high 
Table 1. Patient clinical and pathological characteristics

\begin{tabular}{|c|c|}
\hline Feature & Number of cases \\
\hline \multicolumn{2}{|l|}{ Sex } \\
\hline Female & 24 \\
\hline Male & 81 \\
\hline \multicolumn{2}{|c|}{ Grading (G) } \\
\hline 1 & 2 \\
\hline 2 & 46 \\
\hline 3 & 57 \\
\hline \multicolumn{2}{|l|}{ pT } \\
\hline pT1 & 12 \\
\hline pT2a & 13 \\
\hline pT2b & 11 \\
\hline рТЗа & 8 \\
\hline pT3b & 30 \\
\hline pT4a & 31 \\
\hline \multicolumn{2}{|l|}{$\mathrm{pN}$} \\
\hline 0 & 62 \\
\hline 1 & 14 \\
\hline 2 & 27 \\
\hline 3 & 2 \\
\hline \multicolumn{2}{|l|}{ NDN } \\
\hline 0 & 31 \\
\hline 1 & 28 \\
\hline 2 & 25 \\
\hline 3 & 12 \\
\hline 4 & 6 \\
\hline 5 & 2 \\
\hline 6 & 1 \\
\hline
\end{tabular}

pH buffer (EnVision Flex+ Target Retrieval Solution, High pH: Bufor Tris/EDTA, pH 9; Dako) in PT Link (Dako) pre-treatment module. Following the blocking of intracellular peroxidase (EnVision Flex, Dako) and blocking of non-specific binding sites (Block Surface Blocker, Candor Bioscience $\mathrm{GmbH}$ ) the tissue samples were incubated with anti-ROR $\alpha$ antibody overnight at $4^{\circ} \mathrm{C}$. Afterwards, the samples were incubated with the secondary antibody (EnVision FLEX/HRP, Dako) for 30 minutes. The staining was visualized after a 5-minute incubation with EnVision FLEX DAB + Chromogen, Dako, followed by a hematoxylin staining. The samples were assessed using a Nikon Eclipse 80i light microscope. A positive and negative sample of a skin section was included in each staining cycle, with the omission of the ROR $\alpha$ antibody for the negative control. The expression of ROR $\alpha$ by the tumor cells (TCs) was assessed by counting TCs with a cytoplasmic and/or nuclear staining for $\mathrm{ROR} \alpha$ per 1000 TCs regardless of the intensity of the staining.

\section{Statistical analysis}

The relationships between TCs expression of ROR $\alpha$ and variables such as $\mathrm{pT}, \mathrm{pN}, \mathrm{G}$ and NDN were analyzed using the Mann-Whitney-Wilcoxon test. The statistical analyses were performed using STATISTICA data analysis software (version 13, StatSoft, Inc., Tulsa, OK, USA). A p-value $<0.05$ was considered to be significant.

\section{Results}

Cytoplasmic expression of $\operatorname{ROR} \alpha$ was detected in close to all tested tumor samples (104/105) while nuclear expression was noted in only 3 cases.

\section{Expression of ROR $\alpha$ and lymph node status (pN)}

In the cases of tumors with lymph node involvement ( $n=43$ ), a higher percentage of TCs expressing ROR $\alpha$ was observed (Fig. 1CD), compared to non-metastatic tumors $(n=62)$ (Fig. 1AB).

A correlation between the presence of lymph node metastases and the extent of ROR positive TCs was observed. The percentage of ROR positive TCs was significantly higher in tumors presenting lymph node metastases (Fig. 2).

\section{Expression of ROR $\alpha$ and NDN}

The percentage of TCs expressing ROR $\alpha$ is higher in tumors with non-classic differentiation (Fig. 3).

In tumors with one or more non-classic differentiation types (NDN > 0), the extent of ROR $\alpha$ positive TCs was significantly higher compared with tumors with the classic type of differentiation (NDN = 0) (Fig. 4).

\section{Expression of $\mathrm{ROR} \alpha$ and grading (G)}

We noted a lower percentage of TCs expressing ROR $\alpha$ in poorly differentiated tumors (G3), compared to moderately and higher differentiated tumors (G1 and G2).

\section{ROR $\alpha$ expression in neoplastic cells and tumor stage (pT)}

There was no significant correlation between $\mathrm{ROR} \alpha$ frequency and tumor staging (not shown).

\section{Discussion}

A literature review reveals that $\mathrm{ROR} \alpha$ is a widely distributed nuclear receptor known for its regulatory activity regarding metabolism, inflammation, angiogenesis or 

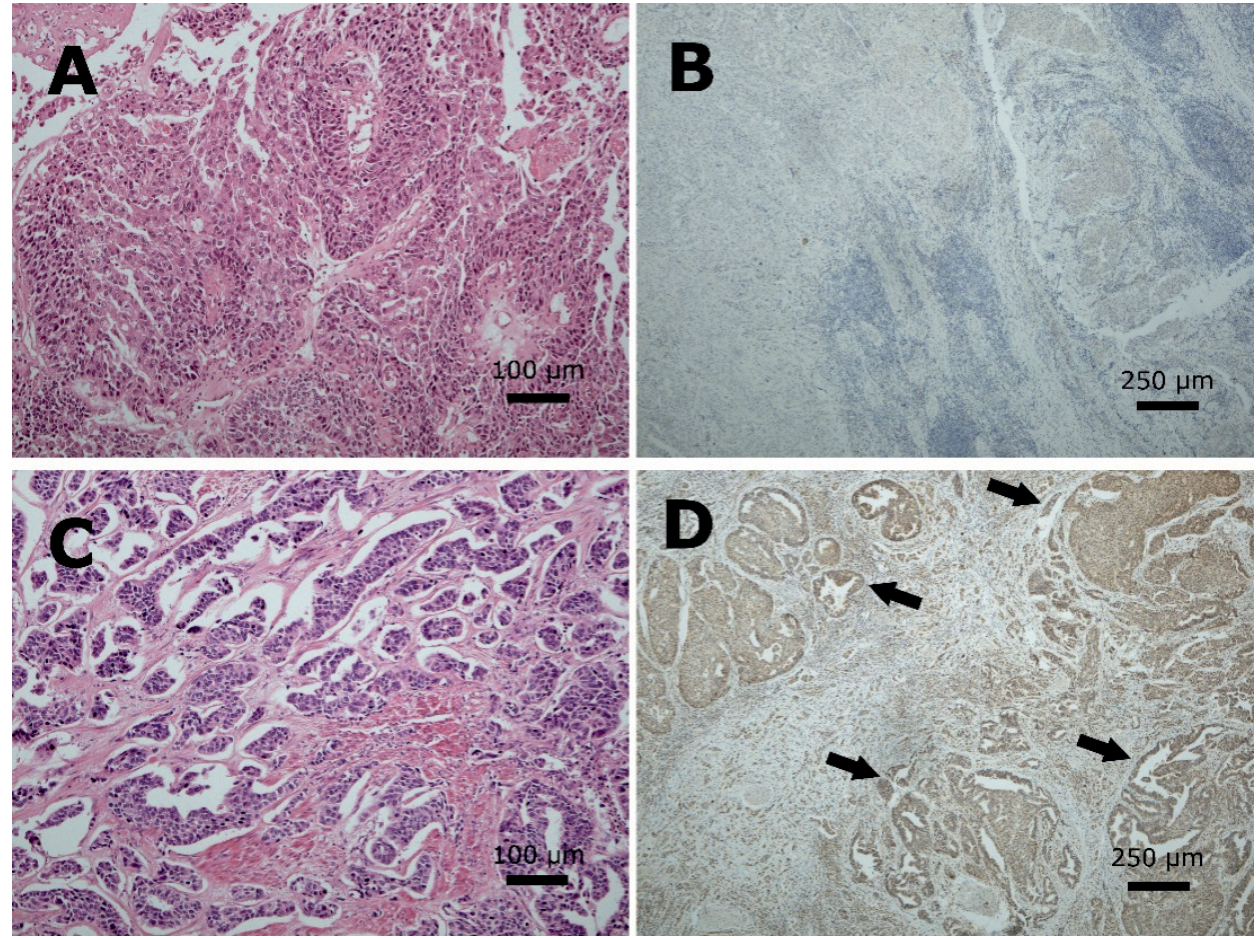

Figure 1. Atypical morphology of a non-metastatic tumor in H\&E staining (A, 100x) is associated with none or few RORpositive tumor cells $(B, 40 x)$. A high percentage of ROR-positive TCs (D, 40x) identifies metastatic tumors with atypical morphology in H\&E staining (C, 40x). Arrows indicate ROR+ TCs

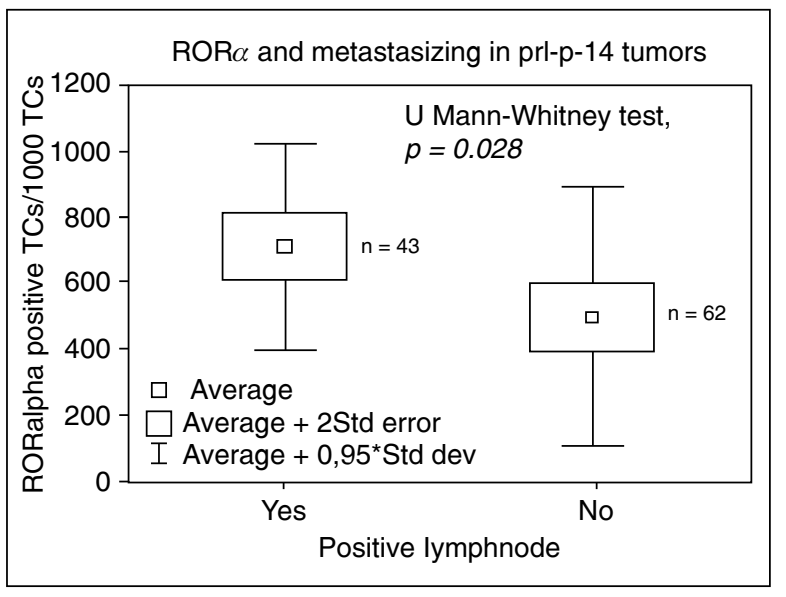

Figure 2. The percentage of ROR positive TCs was about $30 \%$ higher in metastatic tumors in comparison with nonmetastatic tumors

circadian rhythm [17, 31]. Increasingly, retinoid acid receptor-related orphan receptors are being studied in the context of cancer-related processes including gastric cancer, melanoma or colorectal cancer [32]. Fu RD et al. observed that a lowered ROR $\alpha$ expression was associated with worse survival prognosis in hepatocellular carcinoma [13]. In our study, ROR $\alpha$ was weakly expressed (Fig. 1D, Fig. 3D) in every analyzed urothelial tumor. A downregulation of $\mathrm{ROR} \alpha$ expression may be related to the process of neogenesis which led us to analyze the extent of ROR $\alpha$ expression within the tumor. We observed that the percentage of TCs expressing ROR $\alpha$ was notably higher in metastatic tumors compared to tumors without the involvement of regional lymph nodes (Fig. 2). The gain of the ability to metastasize is considered to be the last stage in the progression of urothelial cancer and identifies a highly malignant tumor capable of forming secondary distant tumor sites [33]. The broad extent of weakly-expressed ROR $\alpha$ may indicate a deficit of the transcription factor or perhaps insufficient efficiency of cellular repair systems. We have not found a sufficient explanation of that problem in the available literature. Further research aimed at the identification of ROR $\alpha$-regulated metabolic pathways that result in increased metastasis is necessary. Considering the established role of ROR $\alpha$ in the processes of cell growth and differentiation [34]-beta, and -gamma are transcription factors belonging to the steroid hormone receptor superfamily. During embryonic development RORs are expressed in a spatial and temporal manner and are critical in the regulation of cellular differentiation and the development of several tissues. RORalpha plays a key role in the development of the cerebel- 

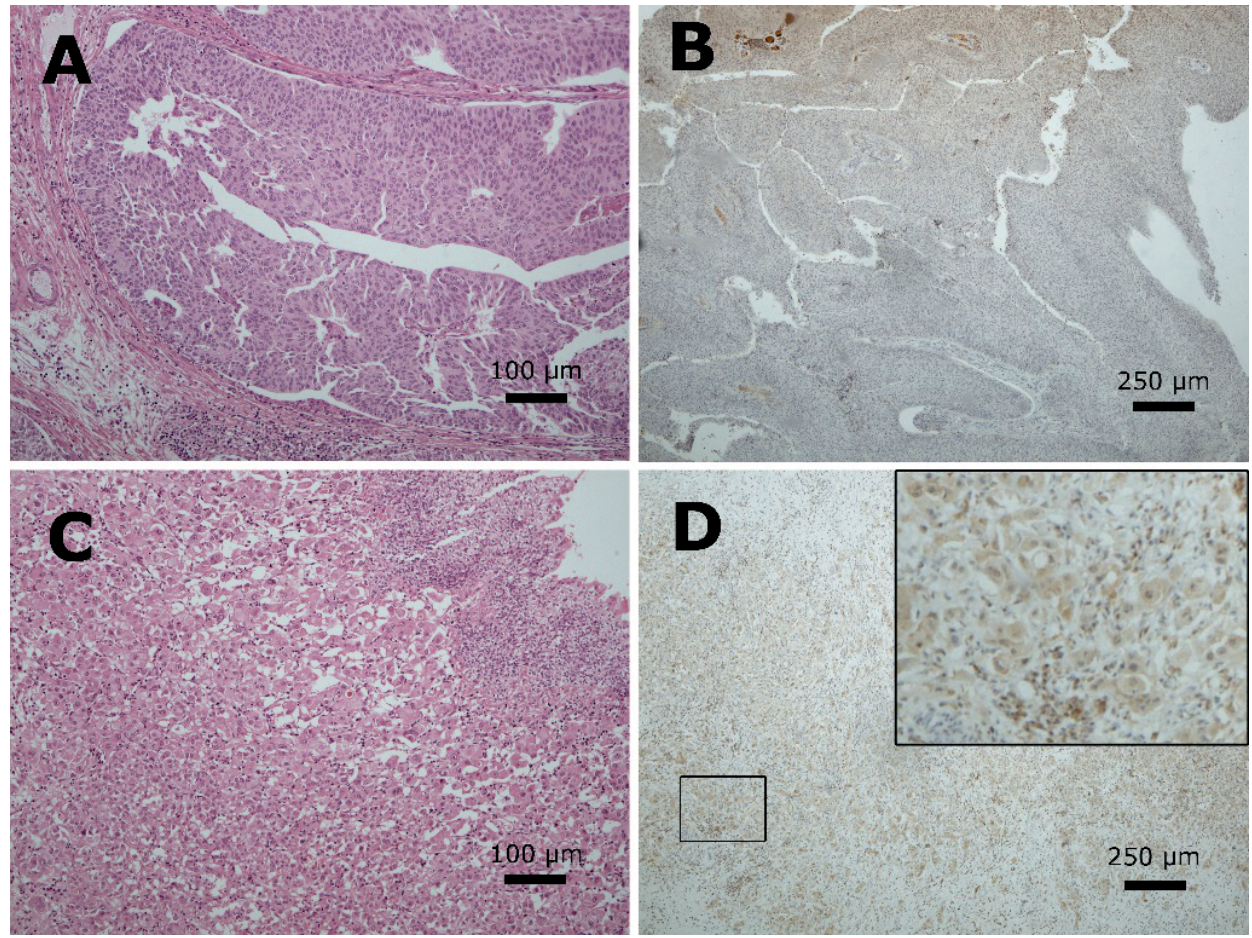

Figure 3. A classic differentiation (A, 100x) is associated with a low frequency of tumor cells expressing ROR (B) (case with $N D N=0,40 x)$. A higher frequency of ROR+ tumor cells $(D, 40 x)$ can be observed in tumors with at least one nonclassic differentiation type (C) (case with NDN > 0, 100x)

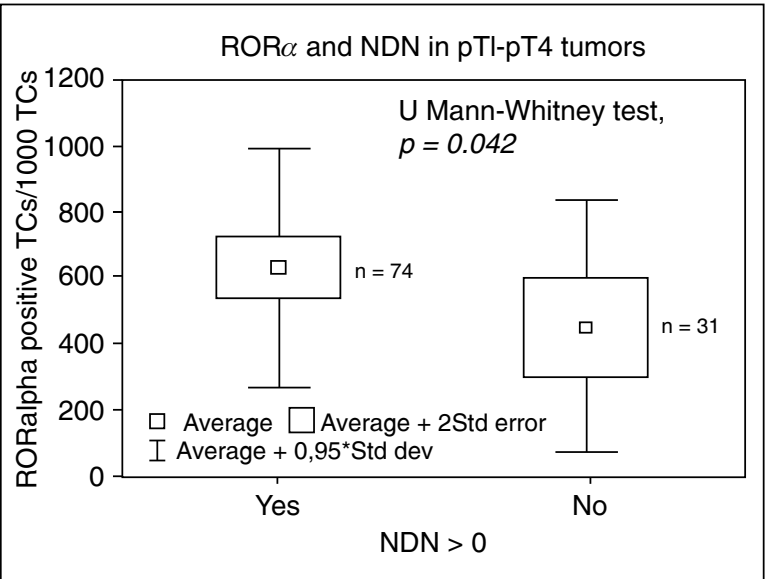

Figure 4. The percentage of ROR positive TCs was about $30 \%$ higher in NDN > 0 tumors in comparison with tumors of only classic type of differentiation

lum particularly in the regulation of the maturation and survival of Purkinje cells. In RORalpha-deficient mice, the reduced production of sonic hedgehog by these cells appears to be the major cause of the decreased proliferation of granule cell precursors and the observed cerebellar atrophy. RORalpha has been implicated in the regulation of a number of other

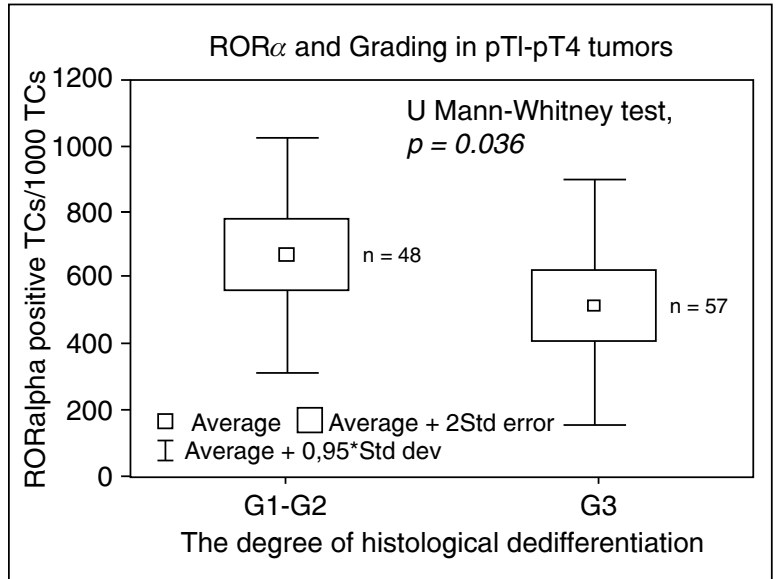

Figure 5. The percentage of ROR positive TCs was about $20 \%$ lower in G3 tumors in comparison with tumors less dedifferentiated (G2)

physiological processes, including bone formation. RORbeta expression is largely restricted to several regions of the brain, the retina, and pineal gland. Mice deficient in RORbeta develop retinal degeneration that results in blindness. RORgamma is essential for lymph node organogenesis. In the intestine RORgamma is required for the formation of several other lymphoid 
tissues: Peyer's patches, cryptopatches, and isolated lymphoid follicles. RORgamma plays a key role in the generation of lymphoid tissue inducer ( $\mathrm{LTi}$, the role of $\operatorname{ROR} \alpha$ warrants investigation in the context of its impact on the increased malignant potential of UBC and its histological differentiation. Xiong $G$ et al. observed suppression of the invasive capacity of breast cancer through ROR $\alpha$ [22]. In our study, we showed that a large extent of weakly-expressed $\operatorname{ROR} \alpha$ was associated with tumors displaying non-classic types of differentiation (Fig. 3CD, Fig. 4) which is a marker of increased malignancy in UBC tumors $[27,28]$. Thus, the influence of $\operatorname{ROR} \alpha$ on non-classic differentiation cannot be dismissed yet it has not been explored in the literature to date. Likewise, the results showing a correlation between $\operatorname{ROR} \alpha$ expression and histological dedifferentiation in UBC are a novel finding. The data obtained in this study show a statistically significant difference in $\mathrm{ROR} \alpha$ expression between moderately differentiated (G2) and poorly differentiated (G3) tumors. We also demonstrated that lower histological malignancy was associated with a higher extent of ROR $\alpha$ expression (Fig. 5), resulting probably from insufficiency of $\operatorname{ROR} \alpha$ depended on cellular repair systems. The biology of UBC is still poorly understood. Therefore, research on the mechanisms of promotion and progression of UBC is highly necessary. ROR $\alpha$ is an interesting potential therapeutic target in various tumors thanks to its ability to be influenced by various agonists and antagonists binding to its ligand binding domain $[35,36]$. This study reinforces that notion demonstrating a potential role of $\mathrm{ROR} \alpha$ in influencing the malignancy of UBC.

\section{Conclusions}

The observed association between the extent of ROR $\alpha$ expression and malignancy of urothelial bladder carcinoma may suggest an important role of that receptor in the progression of UBC. As a transcription factor, $\mathrm{ROR} \alpha$ displays a broad range of regulatory effects involving cell and tissue differentiation. The mechanisms of regulation by $\operatorname{ROR} \alpha$ are not yet fully understood. This study represents another step in the process of understanding those mechanisms and highlights the potential role of $\operatorname{ROR} \alpha$ as a therapeutic target in urothelial bladder cancer.

\section{Grant support}

This study was supported in part by funds for statutory research from Collegium Medicum, Nicolaus Copernicus University.

\section{Conflicts of interest}

The authors declare no conflicts of interest.

\section{List of abbreviations:}

TCs - tumor cells

UBC - urothelial bladder cancer

ND - non-classic differentiation

NDN - non-classic differentiation number

\section{References}

1. Torre LA, Bray F, Siegel RL, et al. Global cancer statistics, 2012. CA Cancer J Clin. 2015; 65(2): 87-108, doi: 10.3322/caac.21262, indexed in Pubmed: 25651787.

2. Wojciechowska U, Didkowska J. Zachorowania i zgony na nowotwory złośliwe w Polsce. Krajowy Rejestr Nowotworów, Centrum Onkologii - Instytut im. odowskiej - Curie, Centrum Onkologii - Instytut im. Marii Skł. ; 2017.

3. Siegel RL, Miller KD, Fedewa SA, et al. Cancer Statistics, 2017. CA Cancer J Clin. 2017; 67(1): 7-30, doi: 10.3322/caac.21387, indexed in Pubmed: 28055103.

4. Berdik C. Unlocking bladder cancer. Nature. 2017; 551(7679): S34-S35, doi: 10.1038/551S34a, indexed in Pubmed: 29117159.

5. Ide H, Miyamoto H. Steroid Hormone Receptor Signals as Prognosticators for Urothelial Tumor. Dis Markers. 2015; 2015: 840640, doi: 10.1155/2015/840640, indexed in Pubmed: 26770009

6. Bladder Cancer - Cancer Stat Facts. https://seer.cancer.gov/statfacts/html/urinb.html.

7. Furuse $\mathrm{H}$, Ozono $\mathrm{S}$. Transurethral resection of the bladder tumour (TURBT) for non-muscle invasive bladder cancer: basic skills. Int $\mathrm{J}$ Urol. 2010; 17(8): 698-699, doi: 10.1111/j.1442-2042.2010.02556.x, indexed in Pubmed: 20649827.

8. Cao M, Yang G, Pan J, et al. Repeated transurethral resection for non-muscle invasive bladder cancer. Int J Clin Exp Med. 2015; 8(1): 1416-1419, indexed in Pubmed: 25785148.

9. Ozono S, Hinotsu S, Tabata S, et al. Nara Uro-Oncology Research Group. Treated natural history of superficial bladder cancer. Jpn J Clin Oncol. 2001; 31(11): 536-540, doi: 10.1093/jjco/hye114, indexed in Pubmed: 11773261

10. Brożyna AA, Jóźwicki W, Skobowiat $\mathrm{C}$, et al. ROR $\alpha$ and ROR $\gamma$ expression inversely correlates with human melanoma progression. Oncotarget. 2016; 7(39): 63261-63282, doi: 10.18632/oncotarget.11211, indexed in Pubmed: 27542227.

11. Jóźwicki W, Brożyna AA, Siekiera J, et al. Expression of Vitamin D Receptor (VDR) Positively Correlates with Survival of Urothelial Bladder Cancer Patients. Int J Mol Sci. 2015; 16(10): 24369-24386, doi: 10.3390/ijms161024369, indexed in Pubmed: 26501255.

12. Cadenas $C$, van de Sandt L, Edlund K, et al. Loss of circadian clock gene expression is associated with tumor progression in breast cancer. Cell Cycle. 2014; 13(20): 3282-3291, doi: 10.4161/15384101.2014.95 4454, indexed in Pubmed: 25485508

13. Fu RD, Qiu CH, Chen HA, et al. Retinoic acid receptor-related receptor alpha (RORalpha) is a prognostic marker for hepatocellular carcinoma. Tumour Biol. 2014; 35(8): 7603-7610, doi: 10.1007/s13277-014-2007-9, indexed in Pubmed: 24798975.

14. Jetten AM, Ueda E. Retinoid-related orphan receptors (RORs): roles in cell survival, differentiation and disease. Cell Death Differ. 2002; 9(11): 1167-1171, doi: 10.1038/sj.cdd.4401085, indexed in Pubmed: 12404115

15. Jetten AM. Retinoid-related orphan receptors (RORs): critical roles in development, immunity, circadian rhythm, and cellular metabolism. Nucl Recept Signal. 2009; 7: e003, doi: 10.1621/nrs.07003, indexed in Pubmed: 19381306.

16. Jetten AM, Kang HS, Takeda Y. Retinoic acid-related orphan receptors $\alpha$ and $\gamma$ : key regulators of lipid/glucose metabolism, inflammation, and insulin sensitivity. Front Endocrinol (Lausanne). 2013; 4: 1, doi: 10.3389/fendo.2013.00001, indexed in Pubmed: 23355833 
17. Cook DN, Kang HS, Jetten AM. Retinoic Acid-Related Orphan Receptors (RORs): Regulatory Functions in Immunity, Development, Circadian Rhythm, and Metabolism. Nucl Receptor Res. 2015; 2, doi: 10.11131/2015/101185, indexed in Pubmed: 26878025

18. Kallen JA, Schlaeppi JM, Bitsch F, et al. X-ray structure of the hRORalpha LBD at $1.63 \mathrm{~A}$ : structural and functional data that cholesterol or a cholesterol derivative is the natural ligand of RORalpha. Structure. 2002; 10(12): 1697-1707, doi: 10.1016/s0969-2126(02)00912-7, indexed in Pubmed: 12467577.

19. Chang MiRa, Dharmarajan V, Doebelin C, et al. Synthetic ROR $\gamma$ t Agonists Enhance Protective Immunity. ACS Chem Biol. 2016; 11(4): 1012-1018, doi: 10.1021/acschembio.5b00899, indexed in Pubmed: 26785144.

20. Jetten AM, Kurebayashi S, Ueda E. The ROR nuclear orphan receptor subfamily: critical regulators of multiple biological processes. Prog Nucleic Acid Res Mol Biol. 2001; 69: 205-247, doi: 10.1016/s00796603(01)69048-2, indexed in Pubmed: 11550795.

21. Moretti RM, Montagnani Marelli M, Motta M, et al. Role of the orphan nuclear receptor ROR alpha in the control of the metastatic behavior of androgen-independent prostate cancer cells. Oncol Rep. 2002; 9(5): 1139-1143, indexed in Pubmed: 12168086.

22. Xiong G, Wang C, Evers BM, et al. ROR $\alpha$ suppresses breast tumor invasion by inducing SEMA3F expression. Cancer Res. 2012; 72(7): 1728-1739, doi: 10.1158/0008-5472.CAN-11-2762, indexed in Pubmed: 22350413 .

23. Slominski AT, Kim TK, Takeda Y, et al. ROR $\alpha$ and ROR $\gamma$ are expressed in human skin and serve as receptors for endogenously produced noncalcemic 20-hydroxy- and 20,23-dihydroxyvitamin D. FASEB J. 2014; 28(7): 2775-2789, doi: 10.1096/fj.13-242040, indexed in Pubmed: 24668754

24. Ou Z, Shi X, Gilroy RK, et al. Regulation of the human hydroxysteroid sulfotransferase (SULT2A1) by ROR $\alpha$ and ROR $\gamma$ and its potential relevance to human liver diseases. Mol Endocrinol. 2013; 27(1): 106-115, doi: 10.1210/me.2012-1145, indexed in Pubmed: 23211525

25. Kottorou AE, Antonacopoulou AG, Dimitrakopoulos FID, et al. Altered expression of NFY-C and RORA in colorectal adenocarcinomas. Acta Histochem. 2012; 114(6): 553-561, doi: 10.1016/j.acthis.2011.10.005, indexed in Pubmed: 22104449.

26. Jóźwicki W, Skok Z, Brożyna A et al. Urological Oncology Prognostic and diagnostic implications of histological differentiation in invasive urothelial cell carcinoma of the bladder: variant or non-classic dif- ferentiation number. Central European Journal of Urology. 2010; 63 112-116, doi: 10.5173/ceju.2010.03.art1.

27. Domanowska E, Jozwicki W, Domaniewski J, et al. Muscle-invasive urothelial cell carcinoma of the human bladder: multidirectional differentiation and ability to metastasize. Hum Pathol. 2007; 38(5): 741-746, doi: 10.1016/j.humpath.2006.11.001, indexed in Pubmed: 17306328.

28. Jozwicki W, Domaniewski J, Skok Z, et al. Usefulness of histologic homogeneity estimation of muscle-invasive urinary bladder cancer in an individual prognosis: a mapping study. Urology. 2005; 66(5): 1122-1126, doi: 10.1016/j.urology.2005.06.134, indexed in Pubmed: 16286151

29. Jóźwicki W, Brożyna AA. Does stem cell marker Oct4a expression affect urothelial bladder cancer phenotype? In Sokolowska B (ed): Civilization and Social Diseases, Pope John II University in Biała Podlaska, Institute of Health: Biała Podlaska, Poland. ; 2010: 43-53.

30. International Agency for Research on Cancer. WHO Classification of Tumours of the Urinary System and Male Genital Organs, 4th edition. Lyon: International Agency for Research on Cancer. ; 2016.

31. Chauvet C, Vanhoutteghem A, Duhem C, et al. Control of gene expression by the retinoic acid-related orphan receptor alpha in HepG2 human hepatoma cells. PLoS One. 2011; 6(7): e22545, doi: 10.1371/journal.pone.0022545, indexed in Pubmed: 21818335.

32. Fan J, Lv Z, Yang G, et al. Retinoic Acid Receptor-Related Orphan Receptors: Critical Roles in Tumorigenesis. Front Immunol. 2018: 9: 1187, doi: 10.3389/fimmu.2018.01187, indexed in Pubmed: 29904382

33. Jóźwicki W, Brożyna AA, Siekiera J. Expression of OCT4A: the first step to the next stage of urothelial bladder cancer progression. Int J Mol Sci. 2014; 15(9): 16069-16082, doi: 10.3390/ijms150916069, indexed in Pubmed: 25216339

34. Jetten AM, Joo JH. Retinoid-related Orphan Receptors (RORs): Roles in Cellular Differentiation and Development. Adv Dev Biol. 2006; 16: 313-355, doi: 10.1016/S1574-3349(06)16010-X, indexed in Pubmed: 18418469.

35. Dong C, Yuan L, Dai J, et al. Melatonin inhibits mitogenic cross-talk between retinoic acid-related orphan receptor alpha (RORalpha) and ERalpha in MCF-7 human breast cancer cells. Steroids. 2010; 75(12): 944-951, doi: 10.1016/j.steroids.2010.06.002, indexed in Pubmed: 20558189

36. Du J, Huang C, Zhou B, et al. Isoform-specific inhibition of ROR alpha-mediated transcriptional activation by human FOXP3. J Immunol. 2008; 180(7): 4785-4792, doi: 10.4049/jimmunol.180.7.4785, indexed in Pubmed: 18354202 